\title{
Red blood cell folate levels in Canadian Inuit women of childbearing years: influence of food security, body mass index, smoking, education, and vitamin use
}

\author{
Kait Duncan ${ }^{1} \cdot$ Anders C. Erickson $^{2} \cdot$ Grace M. Egeland $^{3,4} \cdot$ Hope Weiler $^{5} \cdot$ Laura T. Arbour $^{1,6,7}$
}

Received: 5 December 2017 / Accepted: 20 April 2018 / Published online: 9 May 2018

(C) The Author(s) 2018

\begin{abstract}
Background The benefits of folic acid for prevention of congenital anomalies are well known. For the Inuit of Canada, where vitamin use is low and access to folate-rich foods limited, fortification is likely a major source of intake. We sought to determine whether red blood cell folate (RBCF) levels of Inuit women reached accepted target levels.

Methods The Inuit Health Survey, 2007-2008, included evaluation of RBCF levels among 249 randomly selected non-pregnant women of reproductive age. Using descriptive statistics and linear regression analyses, RBCF levels were assessed and compared across several socio-demographic variables to evaluate the characteristics associated with RBCF status.

Results Mean (SD) RBCF levels of $935.5 \mathrm{nmol} / \mathrm{L}( \pm 192)$ reached proposed target levels (> $906 \mathrm{nmol} / \mathrm{L})$; however, $47 \%$ of women had lower than target levels. In bivariate analysis, non-smoking, higher education, higher income, food security, increased body mass index, and vitamin use were each significantly associated with higher RBCF. Increased levels of smoking had a negative association with RBCF levels $(-5.8 \mathrm{nmol} / \mathrm{L}$ per cigarette smoked per day $(p=0.001))$. A total of $6.8 \%$ of women reported taking vitamin supplements, resulting in a $226 \mathrm{nmol} / \mathrm{L}$ higher RBCF level on average compared to non-users $(p<0.001)$.

Conclusion While mean levels of folate reached target levels, this was largely driven by the small number of women taking vitamin supplements. Our results suggest that folate status is often too low in Inuit women of childbearing years. Initiatives to improve food security, culturally relevant education on folate-rich traditional foods, vitamin supplements, and smoking cessation/ reduction programs may benefit Inuit women and improve birth outcomes.
\end{abstract}

\section{Résumé}

Objectif Les bienfaits de l'acide folique pour prévenir les anomalies congénitales sont connus. Pour les Inuits du Canada, qui ont une faible consommation de vitamines et un accès limité aux aliments riches en folates, les aliments enrichis sont probablement une importante source d'acide folique. Nous avons cherché à déterminer si les niveaux de folate érythrocytaire des femmes inuites atteignent les niveaux cibles acceptés.

Méthode L'Enquête de santé auprès des Inuits (2007-2008) a entre autres évalué les niveaux de folate érythrocytaire de 249 femmes non enceintes mais en âge de procréer sélectionnées au hasard. À l'aide de statistiques descriptives et d'analyses de régression linéaires, nous avons calculé et comparé les niveaux de folate érythrocytaire selon plusieurs variables sociodémographiques afin d'évaluer les caractéristiques associées au statut en folate érythrocytaire.

Laura T. Arbour

larbour@uvic.ca

1 Department of Medicine, Island Medical Program, University of British Columbia, Vancouver, British Columbia, Canada

2 School of Population and Public Health, University of British Columbia, Vancouver, British Columbia, Canada

3 Department of Global Public Health and Primary Care, Bergen, Norway
4 Division of Epidemiology, Norwegian Institute of Public Health, Bergen, Norway

5 School of Human Nutrition, McGill University Macdonald Campus, Ste Anne de Bellevue, Quebec, Canada

6 Division of Medical Sciences, University of Victoria, Victoria, British Columbia, Canada

7 UBC Department of Medical Genetics, Island Medical Program, University of Victoria, Medical Sciences Building, Rm 104, 3800 Finnerty Rd, Victoria, British Columbia V8P 5C2, Canada 
Résultats Les niveaux moyens (É.-T.) de folate érythrocytaire de 935,5 nmol/L $( \pm 192)$ atteignaient les niveaux cibles proposés (> $906 \mathrm{nmol} / \mathrm{L}$ ), mais $47 \%$ des femmes avaient des niveaux inférieurs à la cible. Selon les analyses bivariées, le fait de ne pas fumer, les études supérieures, le revenu élevé, la sécurité alimentaire, l'indice de masse corporelle élevé et la consommation de vitamines présentaient chacune une corrélation significative avec le folate érythrocytaire élevé. Les niveaux de tabagisme élevés présentaient une association négative avec les niveaux de folate érythrocytaire $(-5,8 \mathrm{nmol} / \mathrm{L}$ par cigarette fumée par jour $(p=0,001))$. En tout, $6,8 \%$ des femmes disaient prendre des suppléments vitaminiques, et leurs niveaux de folate érythrocytaire étaient en moyenne plus élevés de $226 \mathrm{nmol} / \mathrm{L}$ que ceux des femmes ne prenant pas de suppléments vitaminiques $(p<0,001)$.

Conclusion Les niveaux moyens de folate atteignaient les niveaux cibles, mais ce résultat était en grande partie attribuable au petit nombre de femmes prenant des suppléments vitaminiques. Nos données indiquent que le statut en folate est souvent trop faible chez les femmes inuites en âge de procréer. Des initiatives d'amélioration de la sécurité alimentaire, une sensibilisation culturellement appropriée aux aliments traditionnels riches en folate, des suppléments vitaminiques et des programmes d'abandon ou de réduction du tabagisme pourraient être bénéfiques pour les femmes inuites et améliorer les issues de la grossesse.

Keywords Inuit $\cdot$ Indigenous $\cdot$ Folic acid $\cdot$ Red blood cell folate $\cdot$ Body mass index $\cdot$ Food security

Mots-clés Inuits $\cdot$ Autochtones $\cdot$ Acide folique $\cdot$ Folate érythrocytaire $\cdot$ Indice de masse corporelle $\cdot$ Sécurité alimentaire

\section{Introduction}

An adequate maternal blood folate level during the periconceptional period significantly reduces the likelihood of a neural tube defect at birth (Czeizel and Dudas 1992). For this reason, Canada introduced mandatory folic acid fortification of cereal and grain products in November 1998 as a public health measure to reduce the incidence of neural tube defects (Public Health Agency of Canada 1998). In addition, there is increasing evidence that periconceptional folic acid intake also decreases the risk of other congenital malformations, including heart defects (Ionescu-Ittu et al. 2009; Czeizel et al. 2004; Czeizel et al. 2015). It has been previously observed that Inuit, residing in Canada's Northern regions of Baffin Island, Nunavut and Nunavik, had nearly twice the rate of total birth defects compared to non-Inuit in other parts of the country (Arbour et al. 2004), increased rates which persist in more recent assessments, especially for congenital heart defects (Public Health Agency of Canada 2013). The potential protective effect of folic acid in the reduction of preterm births is also of growing interest (Chen et al. 2015) and is of relevance for Nunavut which has the highest rate of preterm births (12\%) in the country (Mehaffey et al. 2010). Ninety-five percent of births in Nunavut are to Inuit women (Luo et al. 2010).

The traditional diet in Arctic regions is known to be high in fish, sea mammals, and meat, but low in plant food (Kuhnlein et al. 1996). Traditional food sources providing folate within Arctic regions include seaweed, tundra plants, caribou, moose, and ring seal liver (Hidiroglou et al. 2008); however, it has been shown that the modern Inuit derive their dietary folate nearly entirely from fortified market foods (Kuhnlein et al. 2004). Given the low baseline levels of folate in Inuit and other Northern population diets (Arbour et al. 2002; Moffatt 1995), it remains unclear whether such intakes are sufficient to reach target levels of red blood cell folate (RBCF) to prevent congenital anomalies. Daly et al. in their classic study suggest RBCF levels of $906 \mathrm{nmol} / \mathrm{L}$ can be reached with $200 \mathrm{mcg} / \mathrm{day}$ of folate through dietary intake and $400 \mathrm{mcg} / \mathrm{day}$ via a daily folic acid supplement (Daly et al. 1995). However, evidence shows that only a small proportion of Inuit women of childbearing years use multivitamins (Berti et al. 2008). This is compounded by the high prevalence of food insecurity in Canadian Inuit communities which has been noted to associate with lower dietary intake of key nutrients and other biomarkers of nutritional deficiency (Egeland et al. 2011). Furthermore, cigarette smoking is known to adversely influence folate levels (Oncel et al. 2012). Given that approximately $80 \%$ of pregnant Inuit women smoke cigarettes (Mehaffey et al. 2010), assessment of RBCF is pertinent. Thus, the primary objective of the current study was to determine whether the RBCF levels of Inuit women of childbearing age fall within the levels projected to prevent congenital anomalies and possibly reduce other adverse birth outcomes. The secondary objective was to evaluate the characteristics associated with RBCF levels among Inuit women. This analysis of RBCF status in women of childbearing years was part of the cross-sectional Inuit Health Survey (IHS) carried out in conjunction with the International Polar Year (IPY) Program of 2007-2008 (Saudny et al. 2012) which included 36 Inuit communities. 


\section{Methods}

\section{Community involvement and oversight}

The cross-sectional International Polar Year Inuit Health Survey was undertaken to assess the overall health, wellness, and living conditions of Canada's Inuit population residing in three land claim areas (Saudny et al. 2012). The study was developed under the direction of the IPY Steering Committee. The committee included representatives of Inuit organizations and community members from Nunavut, the Inuvialuit region of Northwest Territories (NWT), and Nunatsiavut, along with local and southern researchers, and government organizations. For the full list of the IPY Steering Committee, see http:// www.mcgill.ca/cine/resources/ihs/steering-committees (McGill Centre for Indigenous Peoples' Nutrition and Environment 2018). Scientific research license was received from the Nunavut Research Institute and the Aurora Research Institute (Inuvik, NWT). The Nunatsiavut review board waived the requirement for a license because the IHS team had engaged in an extensive participatory process.

The Steering Committee met on a regular basis to guide the content and methods, and to review the results of the Survey. Research agreements were put in place which considered the use and stewardship of samples and data. Our Inuit partners called for a broad survey and the idea for this specific project resulting in this paper was reviewed by the Steering Committee. Their comments and ideas were incorporated into the work plan. Our drafts and final manuscript were reviewed by the National Inuit Health Surveys Working Group of Inuit Tapiriit Kanatami who contributed to and approved the content of the final manuscript.

\section{Consent}

In support of Inuit oral traditions, a "visual" consent form was created as a DVD in relevant Inuit languages (Inuktitut, Inuinnaqtun, Siglitin, Uummarmiutun, Nattilik, and Inutitut). The DVD depicted the written consent form word-for-word, including all clinical and laboratory procedures. After watching the DVD, participants consenting to participation signed the written consent form (Saudny et al. 2012).

\section{Data collection}

Of a total of 2796 invited households, 1901 participated, with a total enrollment of 2595 adults. Pregnant women were excluded. Participants completed questionnaires, had medical and anthropometric measurements taken, and had fasting venous blood samples drawn. As the majority of communities are coastal, the research was supported by the Canadian Coast Guard Ship Amundsen which housed centrifuges and $-80{ }^{\circ} \mathrm{C}$ freezers for the processing of blood specimens. Of the participants, 249 randomly selected women of childbearing years (between the ages of 18 and 39) were included in the RBCF substudy, with 192 from Nunavut, 23 from Nunatsiavut, and 34 from the Inuvialuit Settlement Region (ISR) (Saudny et al. 2012). Survey data collected of relevance to the current study included age (years), the use of folate-containing supplements and/or multivitamins (yes vs. no), anthropometry (height and weight for calculating body mass index, BMI, $\mathrm{kg} / \mathrm{m}^{2}$ ), waist circumference and percent body fat using leg-to-leg bioelectrical impedance instrument analysis (Tanita TBF-300GS, Arlington Heights, IL, USA), present and past smoking habits, household food security assessments (food secure, moderate food insecurity, and severe food insecurity) (Egeland et al. 2011), education, and income (Saudny et al. 2012). To ensure accuracy, participants were asked to bring their folic acid and other vitamin supplements to the interview. All folic acid supplements and multivitamins containing folic acid were included and are referred to as "vitamins."

\section{Red blood cell folate}

Analysis of blood sample collections included RBCF levels on the 249 women for this substudy (Saudny et al. 2012). Blood was collected in EDTA containing tubes and protected from light. Hematocrit was determined as per standard protocol. For RBCF, $50 \mu$ l of sample was added to $1.0 \mathrm{ml}$ of folate ascorbic acid in a separate tube, followed by mixing and allowing the hemolysate to separate. The samples were then frozen at $-20{ }^{\circ} \mathrm{C}$ and shipped frozen to Nutrasource Diagnostics, Guelph, ON, where they were stored at $-80^{\circ} \mathrm{C}$ until analysis by Quest Diagnostics, San Juan Capistrano, CA.

\section{Quality control}

All Quest Diagnostics' testing locations are subject to Clinical Laboratory Improvement Amendments of 1988 (CLIA-88) certification and maintain current CLIA licenses. Quest Diagnostics' main laboratories are accredited by the College of American Pathologists (CAP).

\section{Statistical analysis}

Descriptive statistics and bivariate (simple) linear regression analyses were used to evaluate the relationships between RBCF levels (nmol/L) and the aforementioned characteristics (Table 1). Pair-wise correlation tests were performed to show the inter-relationships between the variables (Table 2). Sensitivity analyses restricted to nonsupplement users were carried out to evaluate consistency in results. All statistical analyses were conducted using Stata 11-IC. 
Table 1 Red blood cell folate levels (nmol/L) by demographic characteristics $(N=249)$

\begin{tabular}{|c|c|c|c|c|}
\hline Independent variables: categorical & Frequency, $N(\%)$ & RBC folate ${ }^{\mathrm{a}}$ Mean (sd) & $\beta(95 \% \mathrm{CI}) \S$ & $p$ value \\
\hline \multicolumn{5}{|l|}{ Current smoker } \\
\hline No & $46(18.5)$ & $1005.6(217.0)$ & Ref & \\
\hline Yes & $203(81.5)$ & $919.6(182.6)$ & $-86.2(-147.1--25.3)$ & 0.01 \\
\hline \multicolumn{5}{|l|}{ Food security } \\
\hline Secure & $77(30.9)$ & $964.6(190.5)$ & Ref & \\
\hline Moderate insecure & $84(34.5)$ & $933.4(194.9)$ & $-34.2(-94.0-25.7)$ & 0.26 \\
\hline Severe insecure & $76(30.5)$ & $901.9(185.0)$ & $-62.0(-123.9--.004)$ & 0.05 \\
\hline Missing & $10(4.0)$ & $984.4(212.6)$ & - & - \\
\hline \multicolumn{5}{|l|}{ Income } \\
\hline$<\$ 20,000$ & $134(53.8)$ & $920.7(187.4)$ & Ref & \\
\hline$\$ 20,000-\$ 39,999$ & $36(14.5)$ & $938.7(199.4)$ & $18.0(-52.6-88.6)$ & 0.62 \\
\hline$\$ 40,000-\$ 59,999$ & $20(8.0)$ & $991.5(209.4)$ & $70.8(-19.3-160.9)$ & 0.12 \\
\hline$>\$ 60,000$ & $21(8.4)$ & $1015.3(201.6)$ & $94.5(6.3-182.8)$ & 0.04 \\
\hline Did not report/missing & $38(15.3)$ & $911.1(178.5)$ & - & - \\
\hline \multicolumn{5}{|l|}{ Education } \\
\hline Primary & $39(15.7)$ & $883.2(183.9)$ & Ref & \\
\hline Some secondary & $98(39.4)$ & $919.1(183.5)$ & $36.0(-34.7-106.6)$ & 0.32 \\
\hline Completed secondary & $58(23.3)$ & $959.2(177.2)$ & $76.0(-1.3-153.3)$ & 0.05 \\
\hline College/university & $46(18.5)$ & $984.9(219.9)$ & $101.8(20.5-183.0)$ & 0.01 \\
\hline Missing & $8(3.2)$ & $935.4(220.9)$ & - & - \\
\hline \multicolumn{5}{|l|}{ Vitamin use } \\
\hline No & $232(93.2)$ & $920.1(181.4)$ & Ref & \\
\hline Yes & $17(6.8)$ & $1146.1(212.8)$ & $226.0(135.2-316.9)$ & $<0.001$ \\
\hline Continuous & Min-max & Mean (sd) & & \\
\hline Age (years) & $18-39$ & $29.1(6.0)$ & $-1.2(-5.2-2.8)$ & 0.55 \\
\hline Cigarettes/day & $0-40$ & $7.7(6.7)$ & $-5.8(-9.3--2.3)$ & 0.001 \\
\hline Years smoked* & $0-29$ & $13.3(7.5)$ & $-4.7(-7.9--1.6)$ & $<0.01$ \\
\hline Body mass index (BMI) & $17.3-58.3$ & $28.5(6.7)$ & $4.4(0.8-8.0)$ & 0.02 \\
\hline Waist circumference $(\mathrm{cm})$ & $61-156.5$ & $92.7(16.8)$ & $2.0(0.6-3.4)$ & 0.007 \\
\hline Body fat (\%) & $10.5-54.8$ & $33.4(9.8)$ & $3.7(1.2-6.2)$ & 0.004 \\
\hline
\end{tabular}

${ }^{a}$ Red blood cell folate measured in nmol/L, range 373.7-1440.5, mean 935.5 nmol/L (SD 191.9); vitamin use includes multivitamin use with folic acid and folic acid supplements

$\S \beta$ coefficients associated with each independent variable obtained from unadjusted linear regression with RBCF as dependent variable

*Years smoked includes former smokers

\section{Results}

Here, we highlight results from the descriptive and bivariate analyses, all of which are presented in Table 1. The average age of women participating in this substudy was $29.1 \pm 6$ years (Table 1). Eighty-two percent were current smokers, $35 \%$ of whom smoked 10 or more cigarettes per day. Vitamin use was reported by $6.8 \%$. Sixty-five percent reported moderate or severe food insecurity. Forty-two percent had completed high school or had higher education. These descriptive statistics are similar to that of the overall study population from which the random sample was drawn.
The mean RBCF value was $935.5 \pm 192 \mathrm{nmol} / \mathrm{L}$ (range 373.7 to $1440.5 \mathrm{nmol} / \mathrm{L}$ ), indicating considerable variability in values (Fig. 1). The mean RBCF level of non-vitamin users was significantly lower than that of the vitamin users ( $920.1 \pm 181.4$ vs. $1146.1 \pm 212.8 \mathrm{nmol} / \mathrm{L}, p<0.001)$.

In the bivariate linear regression analyses (Table 1), all smoking-related variables had a statistically significant negative relationship with RBCF levels, with a $5.8 \mathrm{nmol} / \mathrm{L}$ lower RBCF level for every additional cigarette smoked per day $(p=0.001)$ and $4.7 \mathrm{nmol} / \mathrm{L}$ lower $\mathrm{RBCF}$ level for every additional year smoked $(p<0.01)$.

There was a clear trend of increasing RBCF levels with increased levels of income and education. Similarly, there was a 
Table 2 Unadjusted correlation coefficients between study variables

\begin{tabular}{|c|c|c|c|c|c|c|c|c|c|}
\hline & $\mathrm{RBCF}$ & Age & Cigs/day & Years smoked & BMI & Education & Food insecurity & Income & Vitamin use \\
\hline $\mathrm{RBCF}$ & 1.0 & & & & & & & & \\
\hline Age (years) & -0.038 & 1.0 & & & & & & & \\
\hline Cigarettes/day & $-0.202 * *$ & 0.053 & 1.0 & & & & & & \\
\hline Years smoked & $-0.184 *$ & $0.645 * *$ & $0.343 * *$ & 1.0 & & & & & \\
\hline BMI $\left(\mathrm{kg} / \mathrm{m}^{2}\right)$ & $0.153 *$ & 0.081 & $-0.141^{*}$ & -0.045 & 1.0 & & & & \\
\hline Education & $0.177 *$ & 0.007 & $-0.255^{* *}$ & $-0.186^{*}$ & $0.148 *$ & 1.0 & & & \\
\hline Food insecure & $-0.131^{*}$ & $0.131^{*}$ & 0.113 & $0.234 * *$ & $-0.172 *$ & $-0.335^{* *}$ & 1.0 & & \\
\hline Income & $0.165^{*}$ & $0.263 * *$ & $-0.178 *$ & 0.039 & $0.234 * *$ & $0.371 * *$ & $-0.367 * *$ & 1.0 & \\
\hline Vitamin use & $0.298 * *$ & 0.034 & -0.057 & -0.058 & -0.123 & $0.185^{*}$ & $-0.145^{*}$ & $0.152 *$ & 1.0 \\
\hline
\end{tabular}

Coefficients are derived from pair-wise correlation tests

RBCF: red blood cell folate (nmol/L); age: increasing years; cigarettes/day: daily number of cigarettes smoked per day for current smokers; years smoked: includes former smokers; BMI: body mass index; education: categorical 1 to 4 where $1=$ primary and $4=$ post-secondary; food insecurity: categorical 1 to 3 where $1=$ food secure, $2=$ moderate insecure, $3=$ severe insecure; income: categorical 1 to 4 where $1=<\$ 20,000 /$ year and $4=>\$ 60,000 /$ year Canadian dollars

*Significant at $p=0.05$

**Significant at $p=0.05$ using Bonferroni correction for multiple testing

$62.0 \mathrm{nmol} / \mathrm{L}(p=0.05)$ higher RBCF level in food-secure participants compared with those with severe food insecurity. There was a statistically significant positive association between RBCF and BMI (4.4 nmol/L per unit BMI, $p=0.02$ ), with similar effects observed with waist circumference and percent body fat.

Sensitivity analysis restricted to non-vitamin users shows similar associations, with the exception of weaker and non-significant associations between RBCF, education, and food security. Additional sensitivity analyses reveal that the 10 participants missing the food (in)security data were more similar to the food-secure group in terms of RBCF levels $(984.4 \pm 212.6 \mathrm{nmol} / \mathrm{L})$, higher education, and income (Table 1). The inter-relationship between the characteristics was measured using pair-wise correlation

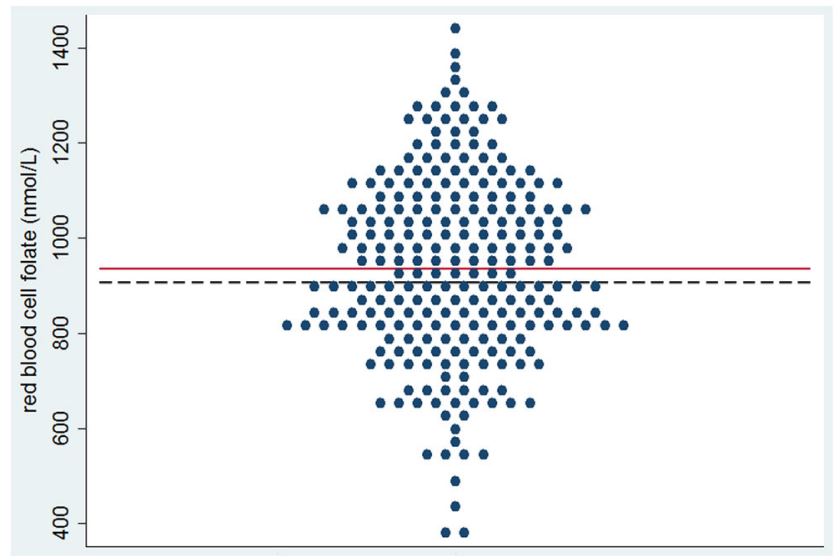

Fig. 1 Scatter plot of red blood cell folate values from Inuit women of childbearing age across all three sample sites. Solid red line denotes population mean $(935.5 \pm 192 \mathrm{nmol} / \mathrm{L})$; dashed black line denotes target reference $(906 \mathrm{nmol} / \mathrm{L})$. Forty-seven percent were below the target analyses (Table 2), which show that higher income, education, and BMI are all positively correlated with food security and RBFC levels.

\section{Discussion}

Folate is a key factor in DNA biosynthesis and cell division (Scott 1999). The knowledge that folate has an important role in reducing birth defects and improving birth outcomes has evolved and strengthened over the last 30 years (Czeizel et al. 2015; Chen et al. 2015). The often-quoted target of RBCF concentration of $906 \mathrm{nmol} / \mathrm{L}$ is based on a dose-response curve by Daly et al. assessing optimum levels of folic acid supplementation and fortification (on the background of assumed levels of daily folate intake) to prevent congenital anomalies, specifically neural tube defects (Daly et al. 1995). With a measured mean RBCF level of $935.5 \pm 192 \mathrm{nmol} / \mathrm{L}$, our findings suggest that at the population level, the average Inuit woman of childbearing age has a sufficient folate/folic acid intake to reach target levels. Although this is reassuring, it is concerning that $47 \%$ of women were below that target. Of note, fewer than $7 \%$ of the women in this study were using vitamin supplements (mean RBCF level of $920.1 \pm 181.4 \mathrm{nmol} / \mathrm{L}$ ).

The RBCF levels are similar to our previous case-control study of congenital heart malformations, which included 76 Inuit women of childbearing age from Nunavut, whose mean RBCF level was found to be $947.0 \pm 32.0 \mathrm{nmol} / \mathrm{L}$ (Arbour et al. 2007). It is notable that none of the participants were taking vitamins at the time of that study (2003-2004). Mandated fortification together with high bioavailability of 
synthetic folic acid is likely responsible for the reasonable RBCF levels demonstrated in our results. Given the background of a low-folate diet (Arbour et al. 2002; Moffatt 1995), these results may reflect a greater intake of fortified market food, which is relatively low cost and nutrient-poor compared to traditional foods (Kuhnlein et al. 2004; Kuhnlein and Receveur 2007). Although some traditional food sources contain folate (Hidiroglou et al. 2008) (see Table 3), the modern day Inuit derive nearly all their dietary folate from fortified food. An analysis of post-fortification dietary intake carried out by Kuhnlein and Receveur found that traditional food now comprises only $17-28 \%$ of the average daily energy intake of adults in the Northern communities studied, whereas white bread and biscuits (items subject to folic acid fortification) were the third and fourth most commonly consumed market food item by weight after tea and sugar (Kuhnlein and Receveur 2007). Such a grain-based diet is associated with lower income and lower educational attainment elsewhere in Canada (Tarasuk et al. 2010) and may also be relevant in Nunavut (Zienczuk and Egeland 2012; Huet et al. 2012). Of relevance, for those considering pregnancy or in the early weeks of pregnancy, some liver sources of high folate can also contain high levels of retinol (Egeland et al. 2004) and methyl mercury (Laird et al. 2013), which, when consumed in excess, can be harmful to the developing fetus. For example, it is suggested that if ring seal liver is eaten, servings be limited to less than $50 \mathrm{~g}$ during early pregnancy or when there is a possibility of pregnancy (Egeland et al. 2004) or be replaced by other nutrient-rich traditional food (Laird et al. 2013).

To put our results into the Canadian perspective, we can compare our results to the Canadian Health Measures Survey (CHMS), a representative sample of more than 5000 Canadians, of whom 644 were women of reproductive age (20-39), that was conducted over a similar time period as the current study (2007-2009) (Statistics Canada 2010a). The average RBCF of Inuit women in the current study was notably less than that observed among women of childbearing years in the CHMS $(935.5 \pm 192$ vs $1279.0 \pm 50.9 \mathrm{nmol} / \mathrm{L})$. Importantly, $47 \%$ of Inuit women had RBCF levels below target (Fig. 1), which was more than double (22\%) that in

Table 3 Traditional food source of folate

\begin{tabular}{ll}
\hline Food source & Total folate $(\mu \mathrm{g} / 100 \mathrm{~g})$ \\
\hline Ring seal liver & $1003 \pm 218$ \\
Walrus liver & $925 \pm 128$ \\
Seaweed & 447 \\
Caribou liver & $374 \pm 152$ \\
Moose liver & 268 \\
Eggs of Cisco & 250 \\
Caribou kidney & 72.6 \\
Clam flesh & 56.8 \\
\hline
\end{tabular}

Derived from Hidiroglou et al. 2008 the CHMS (Statistics Canada 2010a). Interestingly, Inuit women who reported taking vitamin supplements with folate at the time of the study $(n=17)$ had mean RBCF levels similar to those of the 644 women aged 20-39 in the CHMS ( $1146.1 \pm 212.8$ vs $1279.0 \pm 50.9 \mathrm{nmol} / \mathrm{L}$, respectively).

It is well accepted that even in affluent nations, socioeconomic inequality is associated with decreased diet and nutritional quality in the lower socio-economic tiers (Mullie et al. 2010). Using the 2004 Canadian Community Health Survey (CCHS), Tarasuk et al. (2010) found that women (19-50 years) with lower income and education had a higher prevalence of folate deficiency in comparison to similarly aged women of higher socio-economic status. The same trend has been seen in the US, where ethnicity and low income status have consistently been predictors of low blood folate (Yang et al. 2007), factors relevant to the Inuit women in our study (Huet et al. 2012; Statistics Canada 2010b; Egeland 2010). Only a third of the women in our study were from households considered "food secure," which showed significantly higher overall RBCF levels compared to those reporting moderate or severe food insecurity. Our findings show a positive correlation among BMI, food security, higher income, and education, which has been previously observed in a broader analysis of the IHS, but that study did not include RBCF (Zienczuk and Egeland 2012). Of interest is the associated higher RBCF with greater BMI. Our results are consistent with recent evidence that RBCF is higher among obese people; however, serum concentrations of folate may not necessarily be higher (Bird et al. 2015).

Cigarette smoking reduces RBCF stores and distribution (Oncel et al. 2012). Supporting our findings of negative association of smoking and RBCF, evidence was also seen in the third US National Health and Nutrition Examination Survey where significantly lower RBCF levels were shown in individuals with high smoke exposure (smokers and passive smokers), even after adjusting for dietary folate intake (Mannino et al. 2003). Given that $81.5 \%$ of the participants in our study reported smoking, smoking status remains an important consideration regarding poor RBCF status.

Of our study's 249 participants, only $6.8 \%$ were taking supplements, in contrast to $47 \%$ in a 2004 survey of 20,263 nonpregnant North American women between the ages of 18 and 44 (Sullivan et al. 2009). As determined by the 2006/2007 Canadian Maternity Experiences survey (Public Health Agency of Canada 2009) of 8542 women, $57.7 \%$ (95\% CI 56.4-59.0) took folate periconceptionally ( 1 month prior to pregnancy and continuing for 3 months into pregnancy). However, only $13.6 \%$ of women living in Nunavut reported taking supplements in the periconceptional period. Of further relevance, Berti et al. (2008) reviewed nutrient intake and vitamin use recorded in dietary studies between 1987 and 1999 in 
1300 non-pregnant and non-lactating Arctic women of childbearing years and found that only $5 \%$ were taking multivitamins.

Risk factors for low supplement use include low income and educational achievement (Public Health Agency of Canada 2009; Colapinto et al. 2011). Even in countries with well-developed folic acid promotion and monitoring programs, such as the Netherlands, there is a significant disparity in supplement usage among the highest and lowest socioeconomic groups ( $59 \%$ vs. $22 \%$, respectively) (de Jong-van den Berg 2008). In our study, vitamin use had a significant positive impact on RBCF levels, with a more than $200 \mathrm{nmol} / \mathrm{L}$ higher value among vitamin users.

This evidence underscores the importance of recognizing those women who would benefit most from supplemental folic acid fortification and other programs to improve folate status. Given organogenesis occurs in the first weeks of pregnancy, and few pregnancies are planned, current recommendations are that all women who could become pregnant take a daily multivitamin containing folic acid (Health Canada 2018). Smoking and food insecurity are determinants of reduced folate status; therefore, with increased population prevalence of both, the majority of Inuit women would benefit by health promotion in these areas. Programs to reduce smoking (https://nuquits.gov.nu.ca/) and improve food security (https:// itk.ca/nuluaq-mapping-project/about/) are currently underway. Integration of education on the use of traditional foods with folate, and improved access to folic acid supplements, are interventions that could improve RBCF status and lower risks for adverse birth outcomes.

\section{Limitations}

This was a cross-sectional study with a limited sample size.

\section{Conclusion}

The Inuit Health Survey provided the setting to evaluate the blood folate status of Inuit women of childbearing years, an issue of ongoing concern. The findings of our study are striking in that nearly half of Inuit women do not reach target levels of $\mathrm{RBCF}$, and that lower folate status associates with low income, low education, food insecurity, and smoking. Our results indicate that ongoing health promotion of the benefits of supplemental vitamin use for women of childbearing years should be undertaken, alongside programs to reduce food insecurity and smoking in pregnant women.

Acknowledgements We are grateful to the participants from all communities and to the Inuit Health Survey Steering Committee, the National Inuit Health Surveys Working Group of Inuit Tapiriit Kanatami, and
CINE laboratory manager, Donna Leggee. Kim Nuernberger assisted in earlier data analysis.

\section{Compliance with ethical standards}

A certificate of ethical acceptability from the Institutional Review Board of the McGill Faculty of Medicine was obtained. Participatory standards for carrying out research with Indigenous peoples were adhered to. See Methods section for details.

Conflict of interest The authors declare that they have no conflict of interest.

Open Access This article is distributed under the terms of the Creative Commons Attribution 4.0 International License (http:// creativecommons.org/licenses/by/4.0/), which permits unrestricted use, distribution, and reproduction in any medium, provided you give appropriate credit to the original author(s) and the source, provide a link to the Creative Commons license, and indicate if changes were made.

\section{References}

Arbour, L., Christensen, B., Delormier, T., Platt, R., Gilfix, B., Forbes, P., et al. (2002). Spina bifida, folate metabolism, and dietary folate intake in a Northern Canadian aboriginal population. International Journal of Circumpolar Health, 61(4), 341-351.

Arbour, L., Gilpin, C., Millor-Roy, V., Platt, R., Pekeles, G., Egeland, G. M., et al. (2004). Heart defects and other malformations in the Inuit in Canada: a baseline study. International Journal of Circumpolar Health, 63(3), 251-266.

Arbour, L., Rupps, R., MacDonald, S., Forth, M., Yang, J., Nowdluk, M., et al. (2007). Congenital heart defects in Canadian Inuit: is more folic acid making a difference? Alaska Medicine, 49(2 Suppl), 163-166

Berti, P. R., Soueida, R., \& Kuhnlein, H. V. (2008). Dietary assessment of Indigenous Canadian Arctic women with a focus on pregnancy and lactation. International Journal of Circumpolar Health, 67(4), 349-362.

Bird, J. K., Ronnenberg, A. G., Choi, S. W., Du, F. L., Mason, J. B., \& Liu, Z. H. (2015). Obesity is associated with increased red blood cell folate despite lower dietary intakes and serum concentrations. The Journal of Nutrition, 145(1), 79-86.

Chen, L. W., Lim, A. L., Colega, M., Tint, M. T., Aris, I. M., Tan, C. S., et al. (2015). Maternal folate status, but not that of vitamins B-12 or B-6, is associated with gestational age and preterm birth risk in a multiethnic Asian population. The Journal of Nutrition, 145(1), $113-120$

Colapinto, C. K., O'Connor, D. L., \& Tremblay, M. S. (2011). Folate status of the population in the Canadian Health Measures Survey. CMAJ, 183(2), E100-E106.

Czeizel, A. E., \& Dudas, I. (1992). Prevention of the first occurrence of neural-tube defects by periconceptional vitamin supplementation. The New England Journal of Medicine, 327(26), $1832-1835$.

Czeizel, A. E., Dobo, M., \& Vargha, P. (2004). Hungarian cohortcontrolled trial of periconceptional multivitamin supplementation shows a reduction in certain congenital abnormalities. Birth Defects Research. Part A, Clinical and Molecular Teratology, 70(11), 853-861.

Czeizel, A. E., Vereczkey, A., \& Szabo, I. (2015). Folic acid in pregnant women associated with reduced prevalence of severe congenital 
heart defects in their children: a national population-based case-control study. European Journal of Obstetrics, Gynecology, and Reproductive Biology, 193, 34-39.

Daly, L. E., Kirke, P. N., Molloy, A., Weir, D. G., \& Scott, J. M. (1995). Folate levels and neural tube defects. Implications for prevention. JAMA, 274(21), 1698-1702.

Egeland, G. (2010). Inuit Health Survey 2007-2008: Nunavut. Ste-Annede-Bellevue: McGill University.

Egeland, G. M., Berti, P., Soueida, R., Arbour, L. T., Receveur, O., \& Kuhnlein, H. V. (2004). Age differences in vitamin A intake among Canadian Inuit. Canadian Journal of Public Health, 95(6), 465-469.

Egeland, G. M., Johnson-Down, L., Cao, Z. R., Sheikh, N., \& Weiler, H. (2011). Food insecurity and nutrition transition combine to affect nutrient intakes in Canadian arctic communities. The Journal of Nutrition, 141(9), 1746-1753.

Folic acid and neural tube defects. Ottawa: Health Canada, 2018. Available from: https://www.canada.ca/en/public-health/services/ pregnancy/folic-acid.html (Accessed April 3, 2018).

Hidiroglou, N., Peace, R. W., Jee, P., Leggee, D., \& Kuhnlein, H. (2008). Levels of folate, pyridoxine, niacin and riboflavin in traditional foods of Canadian Arctic Indigenous People. Journal of Food Composition and Analysis, 21(6), 474-480.

Huet, C., Rosol, R., \& Egeland, G. M. (2012). The prevalence of food insecurity is high and the diet quality poor in Inuit communities. The Journal of Nutrition, 142(3), 541-547.

Ionescu-Ittu, R., Marelli, A. J., Mackie, A. S., \& Pilote, L. (2009). Prevalence of severe congenital heart disease after folic acid fortification of grain products: time trend analysis in Quebec, Canada. $B M J, 338, \mathrm{~b} 1673$.

de Jong-van den Berg, L. T. (2008). Monitoring of the folic acid supplementation program in the Netherlands. Food and Nutrition Bulletin, 29(2 Suppl), S210-S213.

Kuhnlein, H. V., \& Receveur, O. (2007). Local cultural animal food contributes high levels of nutrients for Arctic Canadian Indigenous adults and children. The Journal of Nutrition, 137(4), 1110-1114.

Kuhnlein, H. V., Soueida, R., \& Receveur, O. (1996). Dietary nutrient profiles of Canadian Baffin Island Inuit differ by food source, season, and age. Journal of the American Dietetic Association, 96(2), $155-162$.

Kuhnlein, H. V., Receveur, O., Soueida, R., \& Egeland, G. M. (2004). Arctic indigenous peoples experience the nutrition transition with changing dietary patterns and obesity. The Journal of Nutrition, 134(6), 1447-1453.

Laird, B. D., Goncharov, A. B., Egeland, G. M., \& Chan, H. M. (2013). Dietary advice on Inuit traditional food use needs to balance benefits and risks of mercury, selenium, and $\mathrm{n} 3$ fatty acids. The Journal of Nutrition, 143(6), 923-930.

Luo, Z. C., Senecal, S., Simonet, F., Guimond, E., Penney, C., \& Wilkins, R. (2010). Birth outcomes in the Inuit-inhabited areas of Canada. CMAJ, 182(3), 235-242.

Mannino, D. M., Mulinare, J., Ford, E. S., \& Schwartz, J. (2003). Tobacco smoke exposure and decreased serum and red blood cell folate levels: data from the Third National Health and Nutrition Examination Survey. Nicotine \& Tobacco Research, 5(3), 357-362.

McGill Centre for Indigenous Peoples' Nutrition and Environment. Steering committee members. Montreal: McGill University, 2018. Available from: www.mcgill.ca/cine/resources/ihs/steeringcommittees (Accessed April 3, 2018).
Mehaffey, K., Higginson, A., Cowan, J., Osborne, G. M., \& Arbour, L. T. (2010). Maternal smoking at first prenatal visit as a marker of risk for adverse pregnancy outcomes in the Qikiqtaaluk (Baffin) Region. Rural and Remote Health, 10(3), 1484.

Moffatt, M. E. (1995). Current status of nutritional deficiencies in Canadian aboriginal people. Canadian Journal of Physiology and Pharmacology, 73(6), 754-758.

Mullie, P., Clarys, P., Hulens, M., \& Vansant, G. (2010). Dietary patterns and socioeconomic position. European Journal of Clinical Nutrition, 64(3), 231-238.

Oncel, M. Y., Ozdemir, R., Erdeve, O., \& Dilmen, U. (2012). Influence of maternal cigarette smoking during pregnancy on neonatal serum folate levels. European Journal of Nutrition, 51(3), 385-387.

Public Health Agency of Canada. (1998). Food and drugs act: regulations amending the food and drug regulations (1066). Ottawa, ON: Health Canada. Available from: http://publications.gc.ca/collections/ Collection-R/Gazette/part1/vol131no48/reg-heal.pdf (Accessed April 3, 2018).

Public Health Agency of Canada. (2009). What mothers say: the Canadian Maternity Experiences Survey. Ottawa: Health Canada. Available from: www.canada.ca/content/dam/phac-aspc/migration/ phac-aspc/rhs-ssg/pdf/survey-eng.pdf (Accessed April 3, 2018).

Public Health Agency of Canada. (2013). Congenital Anomalies in Canada 2013: A perinatal health surveillance report. Ottawa, ON: Health Canada. Available from: http://publications.gc.ca/site/eng/ 443924/publication.html (Accessed April 3, 2018).

Saudny H, Leggee D, Egeland G. (2012). Design and methods of the Adult Inuit Health Survey 2007-2008. International Journal of Circumpolar Health, 71(1). DOI: https://doi.org/10.3402/ijch. v71i0.19752.

Scott, J. M. (1999). Folate and vitamin B12. The Proceedings of the Nutrition Society, 58(2), 441-448.

Statistics Canada. (2010a). Canadian Health Measures Survey: Cycle 1 Data Tables 2007 to 2009. Ottawa: Government of Canada. Available from: http://www.statcan.gc.ca/pub/82-623-x/82-623x2009001-eng.pdf (Accessed April 3, 2018).

Statistics Canada. (2010b). Population size and growth of the Inuit and non-aboriginal populations, Canada and Inuit regions, 1996 and 2006. Ottawa: Government of Canada. Available from: http:// www.statcan.gc.ca/pub/89-636-x/2008001/tab/tab1-eng.htm (Accessed April 3, 2018).

Sullivan, K. M., Ford, E. S., Azrak, M. F., \& Mokdad, A. H. (2009). Multivitamin use in pregnant and nonpregnant women: results from the behavioral risk factor surveillance system. Public Health Reports, 124(3), 384-390.

Tarasuk, V., Fitzpatrick, S., \& Ward, H. (2010). Nutrition inequities in Canada. Applied Physiology, Nutrition, and Metabolism, 35(2), 172-179.

Yang, Q. H., Carter, H. K., Mulinare, J., Berry, R. J., Friedman, J. M., \& Erickson, J. D. (2007). Race-ethnicity differences in folic acid intake in women of childbearing age in the United States after folic acid fortification: findings from the National Health and Nutrition Examination Survey, 2001-2002. The American Journal of Clinical Nutrition, 85(5), 1409-1416.

Zienczuk, N., \& Egeland, G. M. (2012). Association between socioeconomic status and overweight and obesity among Inuit adults: International Polar Year Inuit Health Survey, 2007-2008. International Journal of Circumpolar Health, 71(0), 1-7. 